\title{
The Co-existence of an Osteoma with Cholesteatoma in the External Auditory Canal: Report of an Extremely Rare Case
}

\author{
Dıș Kulak Yolunda Osteom ve Kolesteatom Birlikteliği: Çok Nadir Görülen bir Olgunun Sunumu
}

\author{
Gökhan Yalçıner', Ahmet Kutluhan', Hüseyin Çetin², Akif Sinan Bilgen¹ \\ ${ }^{1}$ Department of Otolaryngology, ${ }^{2}$ Department of Radiology, Ankara Atatürk Training and Research Hospital, Ankara
}

\begin{abstract}
The osteomas of the external auditory canal are relatively rare, slow growing benign neoplasms of unknown etiology that usually cause no symptoms. Although cholesteatomas are almost exclusively seen in the middle ear and at mastoid, in rare cases they occur in the external auditory canal.

The co-existence of an osteoma with cholesteatoma in the external auditory canal is extremely rare and only a few cases are reported. In this report we presented a 43 year-old male patient with a cholesteatoma secondary to external auditory canal osteoma.
\end{abstract}

Key words: cholesteatoma; ear ache; ear canal; functional; hearing loss; osteoma

\section{ÖZET}

Dıș kulak yolu osteomları yavaș büyüyen, genellikle belirti vermeyen, etiyolojisi bilinmeyen ve oldukça nadir görülen neoplazilerdir. Kolesteatomlar neredeyse her zaman orta kulakta ve mastoidde görülseler de, nadir durumlarda dıș kulak yolunda da görülebilirler. Dıș kulak yolunda osteom ve kolesteatomun beraber görülmesi çok nadirdir ve literatürde bildirilmiș birkaç olgu vardır. Biz bu yazıda dıș kulak yolunda osteoma sekonder gelișen kolesteatomu olan 43 yașında bir erkek hasta olgusunu sunduk.

Anahtar kelimeler: kolesteatom; kulak ağrısı; kulak yolu; ișlevsel; ișitme kaybl; osteom

\section{Introduction}

The osteomas of the external auditory canal (EAC) are relatively rare, slow growing benign neoplasms of unknown etiology that usually cause no symptoms ${ }^{1,2}$. Although osteomas have been reported in all portions of the temporal bone, the EAC is the most common site $^{3}$. The symptoms of intracanalicular osteomas such

Akif Sinan Bilgen, Bilkent Yolu No: 3, 06800 Ankara, Türkiye, as conductive hearing impairment and aural fullness are the result of auditory canal obstruction ${ }^{1-3}$.

Cholesteatomas are cystic structures lined by keratinizing stratified squamous epithelium with associated periostitis and bone erosion, and are most commonly occur in the middle ear cavity ${ }^{4}$. Although cholesteatomas are almost exclusively seen in the middle ear and mastoid, in rare cases they occur in the EAC ${ }^{4}$.

The co-existence of osteoma and cholesteatoma in the external auditory canal is extremely rare and so far only few cases are reported in the literature ${ }^{2,3}$. Herein, we presented a 43 year-old male patient with an osteoma and a cholestatoma in the EAC, and discussed current literature findings.

\section{Case Report}

A 43 year-old male patient was admitted to our inpatient unit with the complaint of otalgia. From his medical history we learned that he at times has had otalgia in his right ear for the last four years. One month ago the patient began to experience continuous otalgia and associated hearing loss.

Physical examination revealed that a hard mass, covered with skin and completely occluding the EAC. On pure tone audiometry there was mild conductive hearing loss with a pure tone average of $42 \mathrm{~dB}$ on the right ear. Computerized tomography (CT) examination revealed a hyper dense lesion which is thought to be an osteoma originating from the postero-superior part of the EAC and narrowing the bony EAC. There was also a solid tumoral mass just adjacent to the former one which is thought to be a cholesteatoma destroying the inferior bony wall of the EAC, 
expanding into the tympanic cavity and mastoid antrum, and eroding the tegmen tympany. There was liquid in the right mastoid air cells. The ossicular chain, scutum, cochlea, vestibule, semicircular canals, internal auditory canal, and carotid canal contours were normal (Figure 1, 2).

Following the usual preoperative preparations, the patient was operated under general anesthesia with a post auricular approach and a canal wall-down mastoidectomy was performed. There were massive granulation tissue and cholesteatoma filling the mastoid antrum and the middle ear cavity. Facial nerve canal was defective at the level of mastoid segment. The malleus and incus were eroded and the stapes suprastructures could not be observed. An osteoma of approximately $1 \times 1 \mathrm{~cm}$ in diameter occluding the EAC was excised.

The histopathological examination of the specimen was reported as co-existence of an osteoma and a cholesteatoma. Immediate postoperative period and the following six months were uneventful. The mastoid cavity healed without causing any troubles and up to now we did not demonstrate any evidence of recurrence.

\section{Discussion}

External auditory canal cholesteatoma (EACC) is a rare condition with an estimated incidence of 1 to 1.2 per 1000 new patients with otological problems



Figure 1. Three-dimensional reconstruction of computerized tomography showing the osteoma in the external auditory canal.

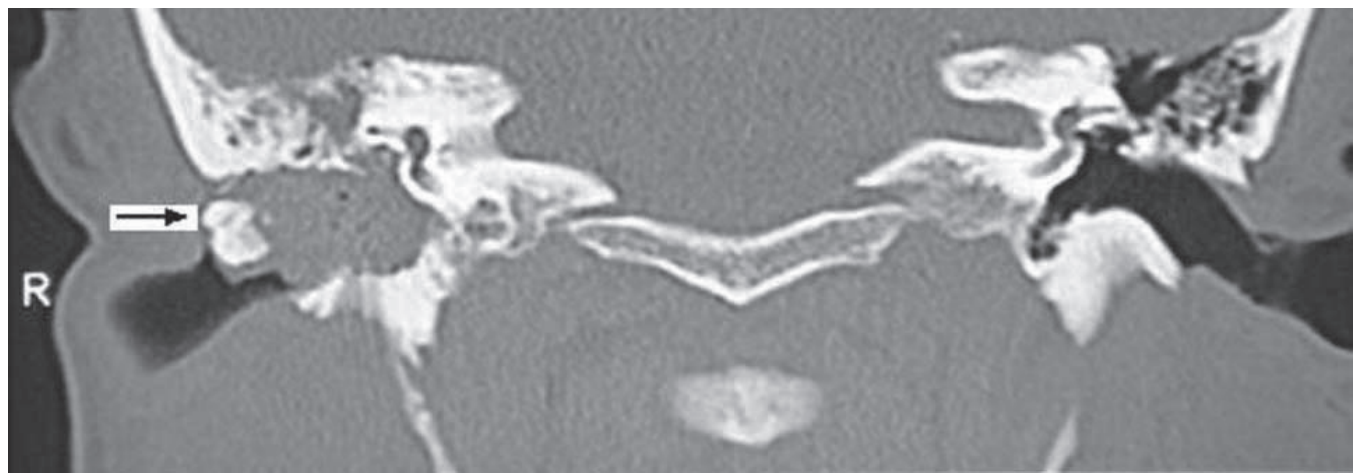

Figure 2. Computerized tomography image showing the osteoma and the adjacent cholesteatoma in the external auditory canal. 
which is 60 times less frequent than the incidence of middle ear cholesteatomas ${ }^{5,6}$. Due to the rareness of the entity, in many studies only a few typical cases were included, hence larger series providing a stronger evidence of possible etiological factors derived from symptoms, clinical and laboratory findings are needed in order to improve diagnostic quality ${ }^{5}$.

Classifications of the EACC may be based on pathogenetic theories. One classification has been suggested by Tos as:

1) Primary EACC,

2) Secondary EACC, and

3) Cholesteatoma associated with congenital atresia of the ear canal.

Secondary EACCs are related to various conditions occurred mainly at the postoperative period ${ }^{5}$. Farrior classified the EACCs into four groups as:

1) Complicating congenital aural atresia and stenosis;

2) Following middle ear surgery or a trauma to the skin of the EAC;

3) Related to a keratosis obturance; and

4) Associated with focal osteitis ${ }^{2,3}$.

The exact etiology of EACC is unclear ${ }^{4}$. Normal epithelial migration from the tympanic membrane and EAC is an important self-cleaning property of the external ear. EACC may be partly related to abnormal epithelial migration, which leads to the local accumulation of squamous epithelium that can evolve into an EACC 4 . More recently immunohistochemical studies reported the probable role of various factors such as vascular endothelial growth factor, fibroblast growth factor, and S100 proteins in the hyper proliferation of the epithelial and sub epithelial tissues to clarify the etiology of $\mathrm{EACC}^{7,8}$.

On the other hand, osteomas are slow growing, asymptomatic benign tumors very rarely involving EAC. Due to their slow growth, auditory canal osteomas develop asymptomatically over a long period without the characteristic clinical features. The symptoms of intra canalicular osteomas result from the obstruction of the auditory channel ${ }^{1}$. In our case, EACC might have resulted by the obstruction caused by osteoma, which prevented the migration of the epithelium.

Due to their slow growing nature, the osteomas and cholesteatomas of the EAC may be silent and asymptomatic for a long time. Otorrhea, pain, and hearing impairment are the most common presenting symptoms $^{6,9,10}$. EACC is easily misdiagnosed as keratosis obturans, which presents with acute and severe otalgia. Additionally keratosis obturans occurs in younger age groups, it's often bilateral, and CT typically demonstrates a soft tissue plug without a focal bone erosion ${ }^{4}$. In our case the existence of bony destructions indicated the cholesteatoma. For an accurate diagnosis a high resolution temporal bone CT scan images and a detailed history should be obtained ${ }^{10}$.

The treatment plan should be individualized in accordance with the individual factors for each patient with EACC. The largeness of the affected bone area determines the limits and technique of the surgery. In case where the mastoid ear cells are involved, a canal wall down mastoidectomy may be indicated. In our case we performed a radical mastoidectomy and a wide meatoplasty to control the cavity during the postoperative period.

Even EACC is a rare entity in the presence of a large osteoma obstructing the EAC, otolaryngologists must be aware of the presence of an EACC and must evaluate the structures behind the osteoma. The temporal bone should be examined by using a CT scan.

\section{References}

1. Sente M. External auditory canal osteoma. Srp Arh Celok Lek 2009; 137: 73-6.

2. Orita Y, Nishizaki K, Fukushima K, et al. Osteoma with cholesteatoma in the external auditory canal. Int J Pediatr Otorhinolaryngol 1998; 43: 289-93.

3. Lee DH, Jun BC, Park CS, et al. A case of osteoma with cholesteatoma in the external auditory canal. Auris Nasus Larynx 2005; 32: 281-4.

4. Heilbrun ME, Salzman KL, Glastonbury CM, et al. External auditory canal cholesteatoma: clinical and imaging spectrum. AJNR Am J Neuroradiol 2003; 24: 751-6.

5. Owen HH, Rosborg J, Gaihede M. Cholesteatoma of the external ear canal: etiological factors, symptoms and clinical findings in a series of 48 cases. BMC Ear Nose Throat Disord 2006; 23: 6-16.

6. Dubach P, Häusler R. External auditory canal cholesteatoma: reassessment of and amendments to its categorization, pathogenesis, and treatment in 34 patients. Otol Neurotol 2008; 29: 941-8.

7. Naim R, Sadick H, Bayerl C, et al. Angiogenic factors in external auditory canal cholesteatoma-fibroblast cell culture. HNO 2005; 53: 952-6.

8. Naim R, Hormann K. The role of S100A1 in external auditory canal cholesteatoma. Oncol Rep 2006; 16: 671-5.

9. Yoon YH, Park CH, Kim EH, et al. Clinical characteristics of external auditory canal cholesteatoma in children. Otolaryngol Head Neck Surg 2008; 139: 661-4.

10. Lu W, Li S, Qin Z. Imaging features and surgical approach of external auditory canal cholesteatoma. Lin Chung Er Bi Yan Hou Tou Jing Wai Ke Za Zhi 2007; 21: 741-3. 